Article

\title{
Indole Derivatives Produced by the Metagenome Genes of the Escherichia coli-Harboring Marine Sponge Discodermia calyx
}

\author{
Feng-Lou Liu ${ }^{1}$ and Xiao-Long Yang ${ }^{2, *}$ \\ 1 Agricultural college, Ningxia University, Yinchuan 750021, Ningxia, China; liufenglou@nxu.edu.cn \\ 2 Innovative Drug Research Centre (IDRC), School of Pharmaceutical Sciences, Huxi Campus, Chongqing \\ University, Chongqing 401331, China \\ * Correspondence: yx119830915@163.com or yx119830915@cqu.edu.cn
}

Academic Editors: Thomas J. Schmidt and Bruno Figadere

Received: 15 February 2017; Accepted: 19 April 2017; Published: 25 April 2017

\begin{abstract}
Three indole derivatives, a novel benzoxazine-indole hybrid (1) and two known indole trimers $(2,3)$, were isolated from the metagenomic library of the marine sponge Discodermia calyx based on functional screening. Their structures were elucidated by extensive spectroscopic analysis and comparison of their NMR data to that of known compounds. The antibacterial assay indicated that only compound $\mathbf{2}$ displayed significant antibacterial activity against Bacillus cereus, with approximately $20 \mathrm{~mm}$ diameter growth inhibition at $10 \mu \mathrm{g} /$ paper. HPLC analyses revealed that compound $\mathbf{2}$ is a newly induced metabolite, and the concentration of $\mathbf{3}$ was obviously enhanced in contrast to negative control, while $\mathbf{1}$ was not detected, allowing us to predict that the formation of $\mathbf{2}$ might be induced by exogenous genes derived from the sponge metagenome, whereas compound 1 could be formed through a non-enzymatic process during the isolation procedure.
\end{abstract}

Keywords: Discodermia calyx; indole derivative; antibacterial activity; metagenomics

\section{Introduction}

Marine sponges and their associated microorganisms have been attracting the attention of chemists and pharmacologists as a very promising potential source of novel bioactive compounds since the discovery of the nucleosides spongothymidine and spongouridine in the marine sponge Cryptotethya crypta in the 1950s [1]. To date, a variety of chemically interesting and biologically significant secondary metabolites have been reported from marine sponges, and most of them have shown significant antibacterial activities [2,3]. There is increasing evidence suggesting that sponge-derived symbiotic bacteria are the original producers of these bioactive compounds $[4,5]$. Unfortunately, only very small fraction of the total sponge-associated bacteria is amenable to cultivation and chemical study, and the vast majority of them remain uncultured, representing an enormous potential source of novel biosynthetic enzymes and secondary metabolites [5,6]. Metagenomic approaches have proven to be powerful tools for accessing the biosynthetic potential of uncultured bacteria metabolic and identifying novel metabolites by use of libraries constructed from isolated nucleic acids $[7,8]$.

The marine sponge Discodermia calyx is considered one of most prolific marine producers of novel biologically active compounds, exemplified by the potent antitumor metabolites calyculins [9], and cytotoxic calyxamide cyclic peptides [10], etc. Previous investigation of the Discodermia calyx metagenomic library led to the isolation of porphyrins, indole antibiotics, and cyclodipeptides [11-15], indicating that the $D$. calyx metagenomic library is worthy of further functional screening-based investigation. Therefore, the metagenomic library, containing $2.5 \times 10^{5}$ clones harboring ca. $35 \mathrm{~kb}$ of 
insert DNAs derived from the marine sponge D. calyx, was re-screened for antibacterial activity using the two-layer overlay method, resulting in the discovery of one positive clone, designated as pDC115, which produced a clear inhibition zone against Bacillus cereus. Further bioassay-guided fractionation yielded three indole derivatives 1-3, including a novel benzoxazine-indole hybrid $\mathbf{1}$ isolated as racemic mixture (Figure 1). Herein, details of the isolation, structural elucidation and antibacterial activities of these compounds are reported.

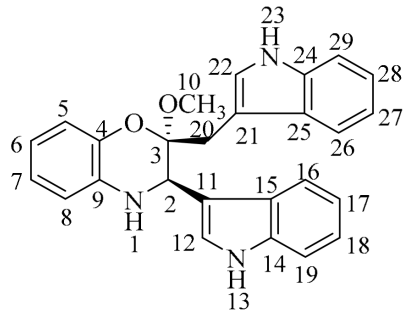

1 (racemic mixture)

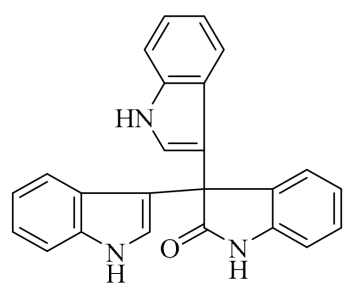

2

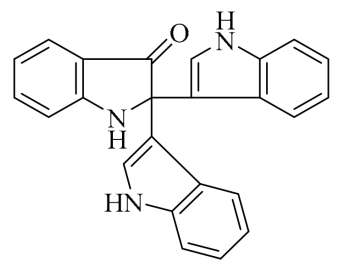

3

Figure 1. The structures of compounds 1-3.

\section{Results and Discussion}

Compound 1 was isolated as a colorless amorphous powder. The positive-ion ESI-TOF-MS and LC-MS showed a pseudo-molecular ion peak $[\mathrm{M}+\mathrm{H}]^{+}$at $m / z 410$. Its molecular formula was determined as $\mathrm{C}_{26} \mathrm{H}_{23} \mathrm{~N}_{3} \mathrm{O}_{2}$ by the HR-ESI-MS peak at $m / z 410.1887$ (calcd for $\mathrm{C}_{26} \mathrm{H}_{24} \mathrm{~N}_{3} \mathrm{O}_{2}$, $m / z$ 410.1863), indicating 17 degrees of unsaturation. The cross-peak correlations of $\mathrm{H}-1$ with $\mathrm{H}-2$, H-5 with H-6, H-7 and H-8, H-12 with H-13, H-16 with H-17, H-18 and H-19, H-22 with H-23, H-26 with H-27, H-28 and H-29 observed in the ${ }^{1} \mathrm{H},{ }^{1} \mathrm{H}-\mathrm{COSY}$ spectrum (Figure 2), allowed us to determine six $\mathrm{H}$-atom systems as follows: from $\mathrm{H}-1$ to $\mathrm{H}-2$, from $\mathrm{H}-5$ to $\mathrm{H}-8$, from $\mathrm{H}-12$ to $\mathrm{H}-13$, from $\mathrm{H}-16$ to H-19, from H-22 to H-23, and from H-26 to H-29. The ${ }^{1} \mathrm{H}-\mathrm{NMR}$ data $\left(\delta_{\mathrm{H}} 10.83(1 \mathrm{H}, \mathrm{s}), 7.57\right.$ (1H, d), $7.30(1 \mathrm{H}, \mathrm{brs}), 7.02(1 \mathrm{H}$, overlap), $6.92(1 \mathrm{H}$, overlap) and $6.81(1 \mathrm{H}, \mathrm{brs}) ; 11.09(1 \mathrm{H}, \mathrm{s}), 7.43(1 \mathrm{H}, \mathrm{d})$, $7.39(1 \mathrm{H}, \mathrm{d}), 7.30(1 \mathrm{H}, \mathrm{brs}), 7.07(1 \mathrm{H}$, overlap) and $6.92(1 \mathrm{H}$, overlap), Table 1$)$, revealed the presence of two trisubstituted indole-ring moieties, which was further confirmed by analysis of the key correlations in HMBC experiments as follows: H-12 with C-14 and C-15, H-16 with C-14, H-17 with C-15, H-18 with C-14, H-19 with C-15, H-22 with C-21, C-24 and C-25, H-26 with C-24, H-27 with C-25, H-28 with C-24, H-29 with C-25. In addition, the ${ }^{1} \mathrm{H}-\mathrm{NMR}$ spectrum showed one broadened ortho-coupled doublet at $\delta_{\mathrm{H}} 6.57(1 \mathrm{H}, \mathrm{d})$ and one broadened singlet at $\delta_{\mathrm{H}} 6.81(1 \mathrm{H}, \mathrm{brs})$, and two triplets at $\delta_{\mathrm{H}} 6.66$ $(1 \mathrm{H}, \mathrm{t})$, and $6.51(1 \mathrm{H}, \mathrm{t})$, suggesting the presence of a 1,2-disubstituted benzene ring. Two indole-ring moieties along with one benzene ring accounted for 16 of 17 degrees of unsaturation, suggesting that the remaining degree of unsaturation had to be present as another ring. Careful analysis of the remaining proton signals combined with the HSQC spectrum and molecular formula revealed the presence of one methylene group $\left(\delta_{\mathrm{H}} 2.89(1 \mathrm{H}, \mathrm{d}), 3.46\left(1 \mathrm{H}\right.\right.$, overlap); $\left.\delta_{\mathrm{C}} 28.7(\mathrm{t})\right)$, one methoxy group $\left(\delta_{\mathrm{H}} 3.17(3 \mathrm{H}, \mathrm{s}) ; \delta_{\mathrm{C}} 48.3(\mathrm{q})\right)$, and one methine group attached to a nitrogen atom $\left(\delta_{\mathrm{H}} 4.46(1 \mathrm{H}, \mathrm{s})\right.$; $\left.\delta_{C} 51.2(\mathrm{~d})\right)$. Further detailed interpretation of the remaining HMBC correlations of H-2 with C-11, C-12 and C-15, H-10 with C-3, H-20 with C-3, C-21 and C-25, combined with the remaining single degree of unsaturation all added up to one ring, allowing us to determine its gross structure as shown in Figure 1. 

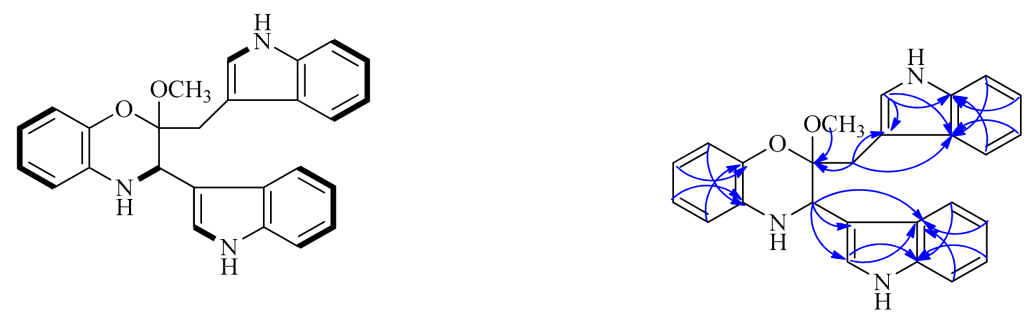

Figure 2. The key ${ }^{1} \mathrm{H},{ }^{1} \mathrm{H}-\mathrm{COSY}$ and HMBC correlations of $\mathbf{1}$.

Table 1. ${ }^{1} \mathrm{H}-(500 \mathrm{MHz})$ and ${ }^{13} \mathrm{C}-\mathrm{NMR}(125 \mathrm{MHz})$ data for $\mathbf{1}$ in DMSO- $d_{6}$ ( $\delta$ in ppm, $J$ in $\mathrm{Hz}$ ).

\begin{tabular}{cccccc}
\hline No. & $\delta_{\mathbf{H}}$ & $\delta_{\mathbf{C}}$ & No. & $\delta_{\mathbf{H}}$ & $\delta_{\mathbf{C}}$ \\
\hline 1 & $5.69(1 \mathrm{H}, \mathrm{s})$ & & 16 & $7.43(1 \mathrm{H}, \mathrm{d}, 8.0)$ & $110.9(\mathrm{~d})$ \\
2 & $4.46(1 \mathrm{H}, \mathrm{s})$ & $51.2(\mathrm{~d})$ & 17 & $6.92(1 \mathrm{H}$, overlap $)$ & $118.2(\mathrm{~d})$ \\
3 & & $97.7(\mathrm{~s})$ & 18 & $7.07(1 \mathrm{H}$, overlap $)$ & $120.7(\mathrm{~d})$ \\
4 & & $132.9(\mathrm{~s})$ & 19 & $7.39(1 \mathrm{H}, \mathrm{d}, 8.5)$ & $123.9(\mathrm{~d})$ \\
5 & $6.57(1 \mathrm{H}, \mathrm{d}, 8.0)$ & $113.8(\mathrm{~d})$ & $20 \mathrm{a}$ & $3.46(1 \mathrm{H}$, overlap $)$ & $28.7(\mathrm{t})$ \\
6 & $6.66(1 \mathrm{H}, \mathrm{t}, 7.9)$ & $119.9(\mathrm{~d})$ & $20 \mathrm{~b}$ & $2.89(1 \mathrm{H}, \mathrm{d}, 15.5)$ & \\
7 & $6.51(1 \mathrm{H}, \mathrm{t}, 7.5)$ & $116.3(\mathrm{~d})$ & 21 & & $107.5(\mathrm{~s})$ \\
8 & $6.81(1 \mathrm{H}, \mathrm{brs})$ & $115.8(\mathrm{~d})$ & 22 & $6.81(1 \mathrm{H}, \mathrm{brs})$ & $124.1(\mathrm{~d})$ \\
9 & & $138.8(\mathrm{~s})$ & 23 & $10.83(\mathrm{H}, \mathrm{s})$ & \\
10 & $3.17(3 \mathrm{H}, \mathrm{s})$ & $48.3(\mathrm{q})$ & 24 & & $133.9(\mathrm{~s})$ \\
11 & & $110.4(\mathrm{~s})$ & 25 & & $126.6(\mathrm{~s})$ \\
12 & $7.30(1 \mathrm{H}, \mathrm{brs})$ & $125.1(\mathrm{~d})$ & 26 & $7.57(1 \mathrm{H}, \mathrm{d}, 8.5)$ & $119.2(\mathrm{~d})$ \\
13 & $11.09(1 \mathrm{H}, \mathrm{s})$ & & 27 & $6.92(1 \mathrm{H}$, overlap $)$ & $118.2(\mathrm{~d})$ \\
14 & & $133.9(\mathrm{~s})$ & 28 & $7.02(1 \mathrm{H}$, overlap $)$ & $120.2(\mathrm{~d})$ \\
15 & & $125.6(\mathrm{~s})$ & 29 & $7.30(1 \mathrm{H}$, brs $)$ & $110.9(\mathrm{~d})$ \\
\hline
\end{tabular}

The positive-ion ESI-TOF-MS and LC-MS (positive) spectra of $\mathbf{1}$ both showed a major fragment ion peak at $m / z 378$ (the most intense peak), which may be formed through loss of a MeOH molecule as shown in Scheme 1. The formula of the major ionic fragment of $\mathbf{1}$ at $\mathrm{m} / z 378$ was determined to be $\mathrm{C}_{25} \mathrm{H}_{20} \mathrm{~N}_{3} \mathrm{O}^{+}$on the basis of positive HR-ESI-MS (calcd. for $\mathrm{C}_{25} \mathrm{H}_{20} \mathrm{~N}_{3} \mathrm{O}^{+} \mathrm{m} / z$ 378.160089; found, 378.162728), which was in accordance with the proposed structure.

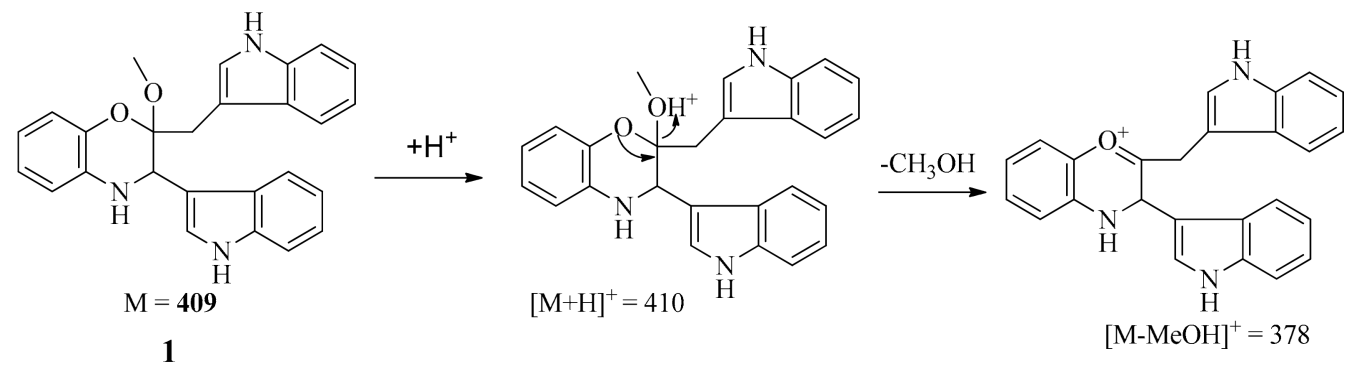

Scheme 1. Possible formation for major fragment of $\mathbf{1}$ in ESI-TOF-MS (positive) and LC-MS (positive) spectra.

The recorded optical rotation (OR) for 1 was $-6.8(c=0.055, \mathrm{MeOH})$. The observed OR was not zero, but the low measured specific rotation value might be due to chiral impurities as seen in the chiral HPLC chromatogram, or it might be a measurement artifact which cannot be avoided since the sample concentration was very low. This sample was further analyzed by HPLC on a chiral ODS-RH phase column $\left(80 \%\right.$ acetonitrile in $20 \%$ water over $\left.40 \mathrm{~min}, 0.3 \mathrm{~mL} / \mathrm{min}, 284 \mathrm{~nm}, 25^{\circ} \mathrm{C}\right)$. Two UV absorption related peaks $\mathbf{1 a}$ and $\mathbf{1} \mathbf{b}$ with almost equal integral area (50:50) appeared in the HPLC 
profile (see Supplementary Materials), indicating that compound $\mathbf{1}$ is an almost 50:50 mixture of two enantiomers $\mathbf{1 a}$ and $\mathbf{1} \mathbf{b}$, further confirming our speculation that compound $\mathbf{1}$ is a racemic mixture. The relative configurations of C-2 and C-3 in 1 were determined by 1D- and 2D-NOESY experiments. The NOESY correlation observed between $\mathrm{H}-2$ and $\mathrm{H}-10$ indicated that $\mathrm{H}-2$ and $\mathrm{H}-10$ should be located on the same side, which was further confirmed by the evident that there is no NOE correlation signals observed when irradiated $\mathrm{H}-2$ and $\mathrm{H}-20$ in 1D-NOE experiment, respectively. Finally, compound 1 was identified as ( \pm )-2-(1H-indol-3-yl)-3-((1H-indol-3-yl)methyl)-3-methoxy-1,2-dihydro-2H-benzo[b][1,4] oxazine. Due to the limited sample amount available, we did not further separate this racemic mixture and determine the absolute configurations.

Two known indole trimers 2 and 3 were identified as trisindoline (2) [16] and 2,2-di(3-indolyl)-3indolone (3) [17], respectively, based on the comparison of their spectroscopic data with those reported in the literature.

The antibacterial activities of compounds 1-3 against Bacillus cereus were investigated using the paper disk method. The results showed that compound 2 exhibited very strong antibacterial activity, with approximately $20 \mathrm{~mm}$ diameter growth inhibition at $10 \mathrm{ug} /$ paper. This compound was first reported as a new antibiotic produced by a bacterium of Vibrio sp. isolated from a marine sponge [16], and subsequently reported as the gene specific product with cytotoxic activity by E. coli expressing the plant-derived oxygenase gene [18]. Compounds 1 and $\mathbf{3}$ exhibited no inhibitory effect against B. cereus. Thus, we predicted that compound 2 would be a gene-specific metabolite in clone PDC115.

Further analysis of HPLC profiles (Figure 3) of negative control (Escherichia coli carrying a void vector) and clone PDC115 indicated that compound 2 was a newly induced compound, while the concentration of $\mathbf{3}$ was obviously enhanced in contrast to negative control. Unfortunately, new compound 1 was not detected in HPLC analysis of the negative control (Escherichia coli carrying a void vector) and clone PDC115, suggesting it might be formed during the isolation procedure.

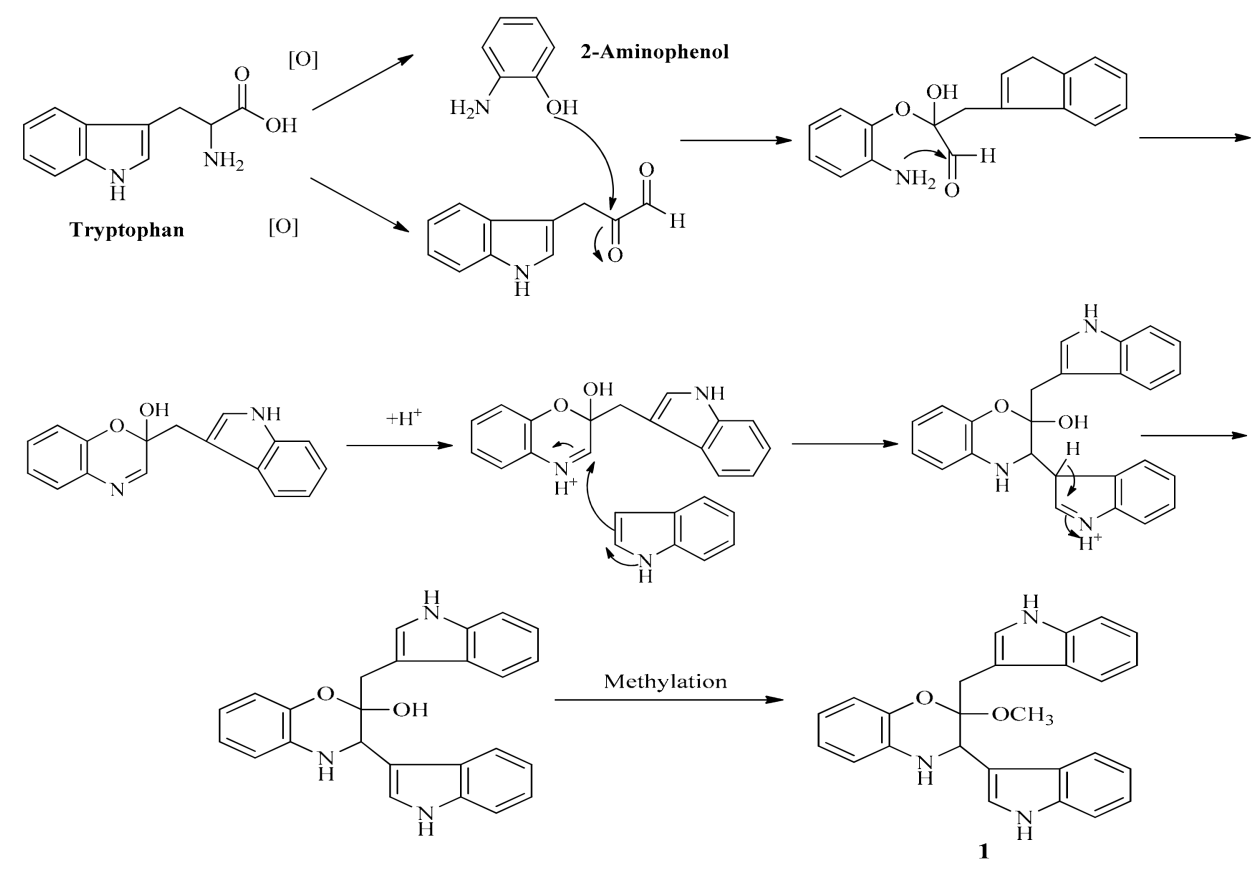

Scheme 2. The proposed formation routine of $\mathbf{1}$ from tryptophan. 

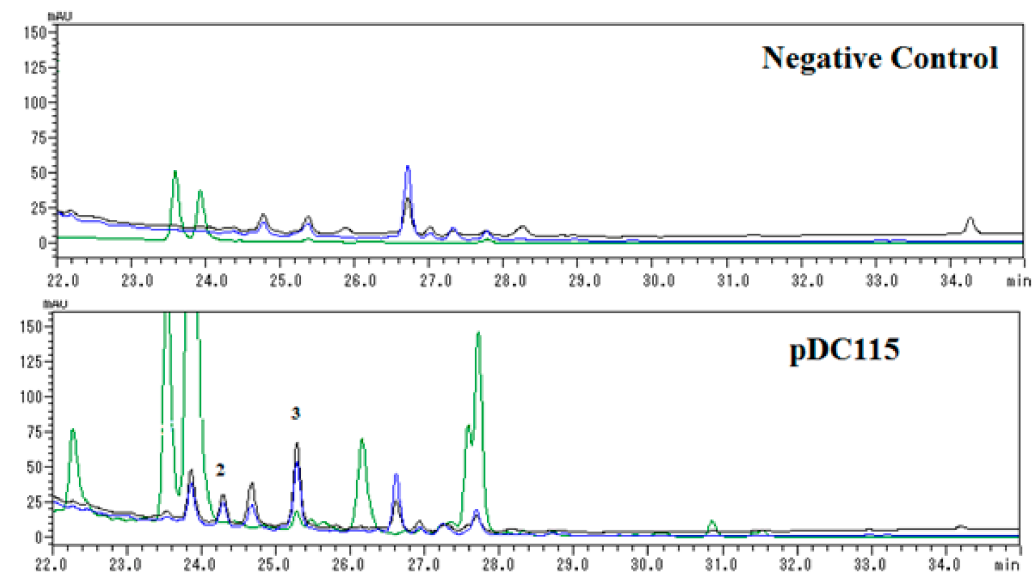

Figure 3. HPLC profiles of $100 \% \mathrm{CH}_{3} \mathrm{OH}$ portions of negative control and pDC115 separated by ODS chromatography. Each sample was prepared to be $10 \mathrm{mg} / \mathrm{mL}$ and $5 \mu \mathrm{L}$ volume was injected for analysis. Elution was monitored by UV absorptions at three representative wavelengths including 254 (black line), 284 (blue line), and 405 (green) $\mathrm{nm}$.

Thus, a hypothetical route of formation shown in Scheme 2 might be envisaged, leading from tryptophan to $\mathbf{1}$ via the unmethylated precursor which could be methylated during the isolation procedure involving methanol. In order to further confirm the proposed formation of $\mathbf{1}$, we checked the crude extract by LC-MS, unfortunately, the proposed key intermediate (the desmethyl form of $\mathbf{1}$ ) was not detected in the crude extract.

\section{Experimental Section}

\subsection{General Experimental Procedures}

1D-(including ${ }^{1} \mathrm{H}$ - and ${ }^{13} \mathrm{C}-\mathrm{NMR}$ ) and 2D-NMR (including COSY, HSQC, HMBC and NOESY) spectra were recorded on an ECX-500 spectrometer (JEOL, Tokyo, Japan) in DMSO- $d_{6}$ with ${ }^{1} \mathrm{H}$ and ${ }^{13} \mathrm{C}$ nuclei observed at 500 and $125 \mathrm{MHz}$, respectively, using TMS as an internal standard, $\delta$ in ppm, $J$ in $\mathrm{Hz}$. HR-MS data were recorded on a Bruker Daltonics micro TOF-MS (Bruker Daltonics, Bremen, Germany) and JEOL JMS-200 MStation (FAB) instrumentz. LC-MS data were obtained from an 1100 series HPLC (Agilent, Santa Clara, USA)-microTOF mass spectrometer (Bruker Daltonics) system, using electrospray ionization with a Cadenza CD-C 18 column (2.0 i.d. $\times 150 \mathrm{~mm}$; Imtakt Co. Ltd. Tokyo, Japan). Optical rotations were measured on a DIP-1000 Digital Polarimeter (JASCO, Tokyo, Japan). The metagenomic library was constructed according to the protocol in the CopyControl ${ }^{\mathrm{TM}}$ Fosmid Libaray Production Kit with pCC1FOS ${ }^{\mathrm{TM}}$ vector (Epicentre Technologies, Madison, WI, USA). DNA was extracted according to DNeasy ${ }^{\circledR}$ Mini Kit (QIAGEN, Tokyo, Japan). Plasmid extraction was done according to Wizard ${ }^{\circledR}$ Plus SV Minipreps DNA Purification System (Promega, Tokyo, Japan). DNA ligation was done according to DNA ligation kit ver. 2.1 (TaKaRa, Tokyo, Japan). Bacillus cereus was obtained from BioVector NTCC Inc. (Tokyo, Japan). The reagents of Tris, EDTA, SDS were supplied by Nacalai Tesque Inc. (Tokyo, Japan). Other reagents including $\mathrm{NaCl}$, phenol, chloroform, ethanol, sodium acetate, isoamyl alcohol, urea, chloramphenicol, and glycerol were supplied by Wako Pure Chemical Industries, Ltd. (Tokyo, Japan).

\subsection{Extraction of Metagenomic DNA from Discodermia calyx}

The Discodermia calyx sample (ca. $100 \mathrm{~g}$ ) was collected in May 2012 from a depth of approximately $10 \mathrm{~m}$ off Shikine-jima Island, an island administered by Japan located in the Philippine Sea, and identified by Professor Toshiyuki Wakimoto in the University of Tokyo. The sample was kept in a freezer at $-80^{\circ} \mathrm{C}$. The voucher specimen (S11-001) was deposited at the Laboratory of Natural 
Products Chemistry, Graduate School of Pharmaceutical Sciences, the University of Tokyo. Before extracting metagenomic DNA, the frozen sponge was first broken into pieces under liquid nitrogen in a mortar, and then pulverized to a fine powder. Subsequently, small portions of the powder was dissolved in lysis buffer (50 mM Tris (pH 7.5), $50 \mathrm{mM}$ EDTA, $350 \mathrm{mM} \mathrm{NaCl}, 8 \mathrm{M}$ urea, 2\% SDS with gently mixing and then incubated at $60^{\circ} \mathrm{C}$ for $1 \mathrm{~h}$. The crude extract DNA was washed three times with an equal volume of phenol-chloroform-isoamyl alcohol (25:24:1) and with chloroform-isoamyl alcohol (24:1), respectively. After precipitation with 2.5 volumes of ethanol and 1/10 volume of $3 \mathrm{M}$ sodium acetate ( $\mathrm{pH}$ 5.2) and centrifugation at $10,000 \times g$ for $20 \mathrm{~min}$ led to afford the DNA pellet, which was further washed with cold 70\% ethanol, air-dried and then re-dissolved in TE buffer. To the metagenomic DNA solution, $0.5 \%$ SDS and $100 \mu \mathrm{g} / \mathrm{mL}$ proteinase $\mathrm{K}$ (TaKaRa) were added. After incubation at $50{ }^{\circ} \mathrm{C}$ for $1 \mathrm{~h}$, the crude metagenomic DNA solution was washed again with phenolchloroform-isoamyl alcohol and chloroform-isoamyl alcohol as described above.

\subsection{Purification of Metagenomic DNA and Library Construction}

The crude metagenomic DNA was size-fractionated by agarose gel electrophoresis $(0.8 \%$ low melting point agarose gel (TaKaRa), $50 \mathrm{~V}$ for $18 \mathrm{~h}$ ). The DNA fragments larger than $35 \mathrm{kbp}$ were recovered from the gel by GELare (Epicentre Technologies) according to the protocol in the CopyControl ${ }^{\mathrm{TM}}$ Fosmid Libaray Production Kit (Epicentre Technologies). The purified DNA was blunt-ended with an End-It DNA End-Repair Kit (Epicentre Technologies), and then ligated into the pCC1FOS fosmid vector (Epicentre Technologies). This vector was subjected to a packaging reaction with a MaxPlax Lambda Packaging Extract (Epicentre Technologies). The packaged vector was used to transfect Escherichia coli EPI300-95 T1R (Epicentre Technologies) and the cells were placed in the LB agar containing chloramphenicol $(12.5 \mu \mathrm{g} / \mathrm{mL})$ as a selection marker, according to the manufacturer's protocol.

\subsection{Antibacterial Screening}

Almost 100 colonies on each plate were grown on LB agar medium containing chloramphenicol ( $15 \mathrm{ug} / \mathrm{mL}$ final concentration), at $30^{\circ} \mathrm{C}$ for 2 days. Subsequently, $0.5 \% \mathrm{LB}$ soft agar medium containing a Bacillus cereus culture solution was poured onto each agar plate, which was cultivated for $12 \mathrm{~h}$ at $37^{\circ} \mathrm{C}$. After the cultivation, the inhibition halo around each colony was monitored. When a positive clone was detected, it was picked up, inoculated into LB medium containing chloramphenicol, and maintained as a glycerol stock at $-80^{\circ} \mathrm{C}$ [13].

\subsection{Extraction and Isolation}

The marine sponge Discodermia calyx metagenomic fosmid library was constructed according to the CopyControl ${ }^{\mathrm{TM}}$ Fosmid Libaray Production Kit (Epicentre Technologies), which contains 250,000 fosmid clones with an average DNA insert size of $40 \mathrm{~kb}$. One positive clone with antibacterial activity against Bacillus cereus, designated pDC115, was found from the library based on functional screening. Thus, the positive clone pDC115 was selected for large-scale cultivation and detailed chemical analysis. The clone pDC115 was firstly pre-cultured overnight in LB broth at $37^{\circ} \mathrm{C}$, and then $10 \mathrm{~mL}$ of culture liquid were transferred as seed into each $2500 \mathrm{~mL}$ Erlenmeyer flask containing $1500 \mathrm{~mL}$ of LB medium. After three days of cultivation in LB broth $(36 \mathrm{~L})$ at $30^{\circ} \mathrm{C}$ on rotary shakers at $120 \mathrm{rpm}$. The medium was subjected to solid phase extraction using Diaion HP-20 resins (250-850 $\mu \mathrm{m}$, Mitsubishi Chemical Corporation, Tokyo, Japan). The methanol extract was subjected to ODS column chromatography (Cosmosil 75C18-PREP, $75 \mu \mathrm{m}$, Nacalai Tesque) eluted with a stepwise gradient system from water to methanol $(0,25 \%, 50 \%, 75 \%$, and $100 \%$ methanol $(v / v))$ to afford five fractions Fr. 1-5. The activity screening indicated that $F r .4$ eluted with $75 \%$ methanol is the active fraction. Further bioassay-guided fractionation of $F r .4$ by repeated Sephadex LH-20 (MeOH) and semipreparative reversed-phase HPLC (Shimadzu, LC-20AD and SPD-20A Prominence Diode Array Detector) using Cosmosil 5C18-PAQ Waters $\left(10 \mathrm{~mm} \times 250 \mathrm{~mm}\right.$, Nacalai Tesque) with a mixture of $\mathrm{H}_{2} \mathrm{O}$ and $\mathrm{CH}_{3} \mathrm{CN}$, both containing 
$0.1 \%$ acetic acid at a flow rate of $2.5 \mathrm{~mL} / \mathrm{min}$ afforded $\mathbf{1}\left(1.2 \mathrm{mg}, t_{\mathrm{R}}=14.5 \mathrm{~min}, 46 \% \mathrm{CH}_{3} \mathrm{CN} \mathrm{in}_{2} \mathrm{O}\right)$, $2\left(1.5 \mathrm{mg}, t_{\mathrm{R}}=26.5 \mathrm{~min}, 84 \% \mathrm{CH}_{3} \mathrm{CN}\right.$ in $\left.\mathrm{H}_{2} \mathrm{O}\right)$ and $3\left(1.2 \mathrm{mg}, t_{\mathrm{R}}=28.5 \mathrm{~min}, 90 \% \mathrm{CH}_{3} \mathrm{CN}\right.$ in $\left.\mathrm{H}_{2} \mathrm{O}\right)$.

(土)-2-(1H-Indol-3-yl)-3-((1H-indol-3-yl)methyl)-3-methoxy-1,2-dihydro-2H-benzo[b][1,4] oxazine (1): colorless amorphous powder; $[\alpha]_{\mathrm{D}}^{24}=-6.8^{\circ}(c 0.055, \mathrm{MeOH}) ;{ }^{1} \mathrm{H}$ - and ${ }^{13} \mathrm{C}-\mathrm{NMR}$ data: Table $1 ; \mathrm{HR}-\mathrm{ESI}-\mathrm{MS}$ at $m / z$ 410.1887 (calcd. for $\mathrm{C}_{26} \mathrm{H}_{24} \mathrm{~N}_{3} \mathrm{O}_{2}, m / z$ 410.1863).

Trisindoline (2): colorless amorphous powder; ${ }^{1} \mathrm{H}-\mathrm{NMR}$ (DMSO- $\left.d_{6}\right)$ : two tri-substituted indole-ring proton signals at $\delta_{\mathrm{H}} 7.33(2 \mathrm{H}, \mathrm{d}), 7.27(2 \mathrm{H}, \mathrm{m}), 7.03(2 \mathrm{H}, \mathrm{t}), 6.90(2 \mathrm{H}, \mathrm{s})$ and $6.80(2 \mathrm{H}, \mathrm{t})$, and one di-substituted indole proton signals at $\delta_{\mathrm{H}} 7.27(1 \mathrm{H}, \mathrm{m}), 7.25(1 \mathrm{H}, \mathrm{m}), 7.05(1 \mathrm{H}, \mathrm{d})$ and $6.98(1 \mathrm{H}, \mathrm{t})$; HR-ESI-MS at $m / z 364.1470$ (calcd. for $\mathrm{C}_{24} \mathrm{H}_{18} \mathrm{~N}_{3} \mathrm{O}, 364.1444$ ).

2,2-Di(3-Indolyl)-3-indolone (3): colorless amorphous powder; ${ }^{1} \mathrm{H}-\mathrm{NMR}$ (DMSO- $d_{6}$ ): two trisubstituted indole-ring proton signals at $\delta_{\mathrm{H}} 10.95(2 \mathrm{H}, \mathrm{s}, \mathrm{NH}), 7.31(2 \mathrm{H}, \mathrm{d}), 7.29(2 \mathrm{H}, \mathrm{m}), 6.99(2 \mathrm{H}, \mathrm{t}), 6.80(2 \mathrm{H}, \mathrm{s})$ and $6.80(2 \mathrm{H}, \mathrm{t})$, and one di-substituted indole proton signals at $\delta_{\mathrm{H}} 8.10(1 \mathrm{H}, \mathrm{s}, \mathrm{NH}), 7.47(1 \mathrm{H}, \mathrm{d})$, $7.44(1 \mathrm{H}, \mathrm{t}), 6.91(1 \mathrm{H}, \mathrm{d})$ and $6.70(1 \mathrm{H}, \mathrm{t})$; HR-ESI-MS at $m / z 364.1442$ (calcd. for $\mathrm{C}_{24} \mathrm{H}_{18} \mathrm{~N}_{3} \mathrm{O}, 364.1444$ ).

\subsection{Antibacterial Assay}

The antibacterial activity of compounds 1-3 was determined according to the protocol reported in [13]. Screening plates containing Bacillus cereus were prepared with LB agar medium. All isolated compounds were dissolved in DMSO to a final concentration of $1 \mathrm{mg} / \mathrm{mL}$. Subsequently, 10, 25, 50, and $100 \mathrm{uL}$ were applied to $0.7 \mathrm{~mm}$ paper disks (Advantech, Tokyo, Japan). The disks were placed on the prepared plates and incubated at $30{ }^{\circ} \mathrm{C}$ for $16 \mathrm{~h}$. Inhibition was scored visually, and zones of inhibition were reported as the diameter of the clear zone in millimeters. The assay was conducted in duplicate trials.

\section{Conclusions}

The present work reports three indole derivatives 1-3, including a novel benzoxazine-indole hybrid 1 from Escherichia coli harboring the marine sponge Discodermia calyx metagenomic DNA. HPLC analyses revealed that compound $\mathbf{2}$ is a newly induced metabolite, and the concentration of 3 was obviously enhanced in comparison with the negative control. Compound $\mathbf{1}$ as racemic mixture was not detected in the liquid culture, which leads to the speculation that the formation of 1 could be due to non-enzymatic processes during the isolation procedure. Biological study indicated that only compound 2 displayed significant antibacterial activity against Bacillus cereus, with approximately $20 \mathrm{~mm}$ diameter growth inhibition at $10 \mu \mathrm{g} /$ paper, suggesting that this compound might be a gene-specific metabolite in clone PDC115.

Supplementary Materials: The original spectra of NMR, LC-MS, chiral HPLC analysis, and HR-ESI-MS data for compound 1 are available as Supplementary Materials.

Acknowledgments: This work was financially supported by the Fundamental Research Funds for the Central Universities (No. 0903005203401), the Start-up Fund for the "Hundred Young-Talent Scheme" Professorship provided by Chongqing University in China (No. 0236011104424), and the National Natural Science Foundation of China (31301305).

Author Contributions: The list authors contributed to this work as follows: F.-L. Liu performed the fermentation, extraction, isolation, bioactivity test, structure elucidation of the constituents and prepared the manuscript; X.-L. Yang contributed to the structure elucidation of compounds, manuscript preparation, and revision of this manuscript. All authors approved the final version of the manuscript.

Conflicts of Interest: The authors declare no conflict of interest.

\section{References}

1. Werner, B.; Robert, J.F. The isolation of a new thymine pentoside from sponges. J. Am. Chem. Soc. 1950, 72, $2809-2810$. 
2. Laport, M.S.; Santos, O.C.; Muricy, G. Marine sponges: Potential sources of new antimicrobial drugs. Curr. Pharm. Biotechnol. 2009, 10, 86-105. [CrossRef] [PubMed]

3. Blunt, J.W.; Copp, B.R.; Keyzers, R.A.; Munro, M.H.; Prinsep, M.R. Marine natural products. Nat. Prod. Rep. 2012, 29, 144-222. [CrossRef] [PubMed]

4. Bewley, C.A.D.; Faulkner, J. Lithistid sponges: Star performers or hosts to the stars. Angew. Chem. Int. Ed. 1998, 37, 2162-2178. [CrossRef]

5. Kobayashi, J.; Ishibashi, M. Bioactive metabolites of symbiotic marine microorganisms. Chem. Rev. 1993, 93, 1753-1769. [CrossRef]

6. Lee, Y.K.; Lee, J.H.; Lee, H.K. Microbial symbiosis in marine sponges. J. Microbiol. 2001, 39, 254-264.

7. Kennedy, J.; Flemer, B.; Jackson, S.A.; Lejon, D.P.; Morrissey, J.P.; O'Gara, F.; Dobson, A.D. Marine metagenomics: New tools for the study and exploitation of marine microbial metabolism. Mar. Drugs 2010, 8, 608-628. [CrossRef] [PubMed]

8. Brady, S.F.; Simmons, L.; Kima, J.H.; Schmidt, E.W. Metagenomic approaches to natural products from free-living and symbiotic organisms. Nat. Prod. Rep. 2009, 26, 1488-1503. [CrossRef] [PubMed]

9. Wakimoto, T.; Matsunaga, S.; Takai, A.; Fusetani, N. Insight into binding of calyculin A to protein phosphatase 1: Isolation of hemicalyculin A and chemical transformation of calyculin A. Chem. Biol. 2002, 9, 309-319. [CrossRef]

10. Kimura, M.; Wakimoto, T.; Egami, Y.; Tan, K.C.; Ise, Y.; Abe, I. Calyxamides A and B, cytotoxic cyclic peptides from the marine sponge Discodermia calyx. J. Nat. Prod. 2012, 75, 290-294. [CrossRef] [PubMed]

11. He, R.; Wakimoto, T.; Takeshige, Y.; Egami, Y.; Kenmoku, H.; Ito, T.; Wang, B.; Asakawa, Y.; Abe, I. Porphyrins from a metagenomic library of the marine sponge Discodermia calyx. Mol. Biosyst. 2012, 6, 2334-2338. [CrossRef] [PubMed]

12. He, R.; Wang, B.C.; Zhu, L.C.; Liu, D.F. Antibacterial indole trimer from metagenomic library of marine sponge Discodermia calyx. Chem. J. Chin. Univ. 2013, 34, 2772-2777.

13. Takeshige, Y.; Egami, Y.; Wakimoto, T.; Abe, I. Production of indole antibiotics induced by exogenous gene derived from sponge metagenome. Mol. Biosyst. 2015, 11, 1290-1294. [CrossRef] [PubMed]

14. Yang, X.L.; Wakimoto, T.; Takeshige, Y.; He, R.; Egami, Y.; Awakawa, T.; Abe, I. Indole-porphyrin hybrids produced by metagenomics. Bioorg. Med. Chem. Lett. 2013, 23, 3810-3813. [CrossRef] [PubMed]

15. He, R.; Wang, B.; Wakimoto, T.; Wang, M.; Zhu, L.; Abe, I. Cyclodipeptides from metagenomic library of a Japanese marine sponge. J. Braz. Chem. Soc. 2013, 24, 1926-1932. [CrossRef]

16. Kobayashi, M.; Aoki, S.; Gato, K.; Matsunami, K.; Kurosu, M.; Kitagawa, I. Marine natural products. XXXIV. Trisindoline, a new antibiotic indole trimer, produced by a bacterium of Vibrio sp. separated from the marine sponge Hyrtios altum. Chem. Pharm. Bull. 1994, 42, 2449-2451. [CrossRef] [PubMed]

17. Bell, R.; Carmeli, S. Vibrindole A, a metabolite of the marine bacterium, Vibrio parahaemolyticus, isolated from the toxic mucus of the boxfish Ostracion cubicus. J. Nat. Prod. 1994, 57, 1587-1590. [CrossRef] [PubMed]

18. Yoo, M.; Choi, S.U.; Choi, K.Y.; Yon, G.H.; Chae, J.C.; Kim, D.; Zylstra, G.J.; Kim, E. Trisindoline synthesis and anticancer activity. Biochem. Biophys. Res. Commun. 2008, 376, 96-99. [CrossRef] [PubMed]

Sample Availability: Not Available.

(C) 2017 by the authors. Licensee MDPI, Basel, Switzerland. This article is an open access article distributed under the terms and conditions of the Creative Commons Attribution (CC BY) license (http:/ / creativecommons.org/licenses/by/4.0/). 